\title{
ERP, Capital Management and Profitability: An Empirical Study of Chinese Automobile Manufacturers
}

\author{
Yihan WANG ${ }^{1, a}$ and Zhenkun WANG ${ }^{1, b}$ \\ ${ }^{1}$ Nanjing University of Finance and Economics, Nanjing, China

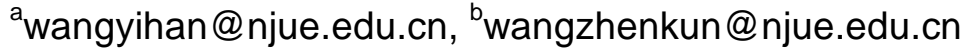

\begin{abstract}
Keywords: ERP, capital management, profitability, automobile manufacturing industry Abstract. Enterprise Resource Planning (ERP) can be considered as an effective tool for planning and controlling of all the resources in an organization. In order to gain competitive advantage, more and more corporations begin to implement ERP projects and deploy information systems to manage their logistics, capital, accounting and other business information. This research is an investigation on the relationship between ERP system and corporations' performance, based on the empirical study of 13 automobile manufacturers who had implemented ERP projects successfully from 2000 to 2015 in mainland China. The results show that the application of ERP systems can improve the manufacturers' capital management and their operational efficiency.
\end{abstract}

\section{Introduction}

Enterprise Resource Planning (ERP) has been implemented by many corporations, such as manufacturers, distributors and service providers, in order to explore an integrated system to manage various business processes across various functions [1]. There are a lot of literatures on the challenge during the implementation of ERP systems and how to successfully deploy ERP projects [2, 3]. However, it is lack of empirical research on the relationship between ERP systems and corporations' performance, especially in developing countries. Therefore, it is significant for professionals to examine whether one's investment on information technology and its business performance is positively related [4].

This study is based on the listed automobile manufacturers' data from Shanghai Stock Exchange and Shenzhen Stock Exchange between 2000 and 2015. By the end of 2013, there are 30 automobile manufacturers has implemented or is implementing ERP projects. According to their information reporting and disclosure, 13 listed companies are selected as samples which had successfully implemented ERP system. Several financial and other indicators are then examined to monitor the changes of their business performance over a 3-year period. Finally, discussions about the findings and limitations of this study are presented.

\section{Literature Review}

ERP was firstly proposed by Gartner Group Inc.in 1990s [5]. The concept was developed from Material Requirements Planning (MRP) and Manufacturing Resource Planning (MRP II). According to the American Production and Inventory Control Society (APICS), ERP is defined as "a framework for organizing, defining, and standardizing the business process necessary to effectively plan and control an organization so the organization can use its internal knowledge to seek external advantage" [6]. It can be achieved through a software package offered by ERP software providers, in order to support the seamless integration of information flow through the organization, such as accounting, inventory, human resources as well as customer information [7].

Since 1990s, there are many researches about the relationship between ERP implementation and corporations' performance. Generally, there are two points of view on this topic. One is that the investment on ERP systems is not related with business performance. For example, Strassmann conducted a questionnaire survey of 38 service providers and found out that the investment on information technology had no relevance to the total returns [8]. The other is that the relationship 
between ERP implementation and business performance is significantly positive. For example, Mcewen, Hunton and Wier conducted an empirical research and concluded that ERP implementation and corporations' performance was positively related [9].

In order to find out the relationship between application of ERP systems and business performance, many researchers has considered the issue of time-delay involving in ERP projects $[10,11]$. Therefore, this study took this consideration and examined the business performance over a 3-year period.

\section{ERP in Chinese automobile manufacturing industry}

Recently the dynamic business environment is becoming increasingly complex and competitive. Investors and business managers require instant financial information for decision making. ERP, as an efficient information system, plays an important role in real-time financial reporting, as well as better logistics and managerial information flow. It is a strategic tool for integrating business data and processes of an organization into one single system, in order to gain a competitive edge in such uncertain environment [12].

For most manufacturers in China, there is a MRPII system for manufacturing management, which include basic modules such as capacity planning, bill of materials, inventories and orders. However, an ERP system expands these functions. Firstly, a lot of managerial functions, for example accounting, cost management and fixed assets management, are added into the original system. Secondly, information throughout the business supply chain can be collected by the system. These information are about customers, suppliers and distributors and ready for future application. Finally, in order to adopt the benefits of ERP, business process reengineering (BPR) is an essential procedure. BPR involves reconsideration and redesign of organizational process so as to achieve dramatic improvement of current performance in cost, service and speed [13].

Currently, the main modules and information flow of ERP system in Chinese automobile manufacturing industry are shown in Figure 1. The main modules include production management, financial management, sales management, resource management and network office automation (OA) system. The information flow among these modules are labelled besides the arrows in Figure 1.

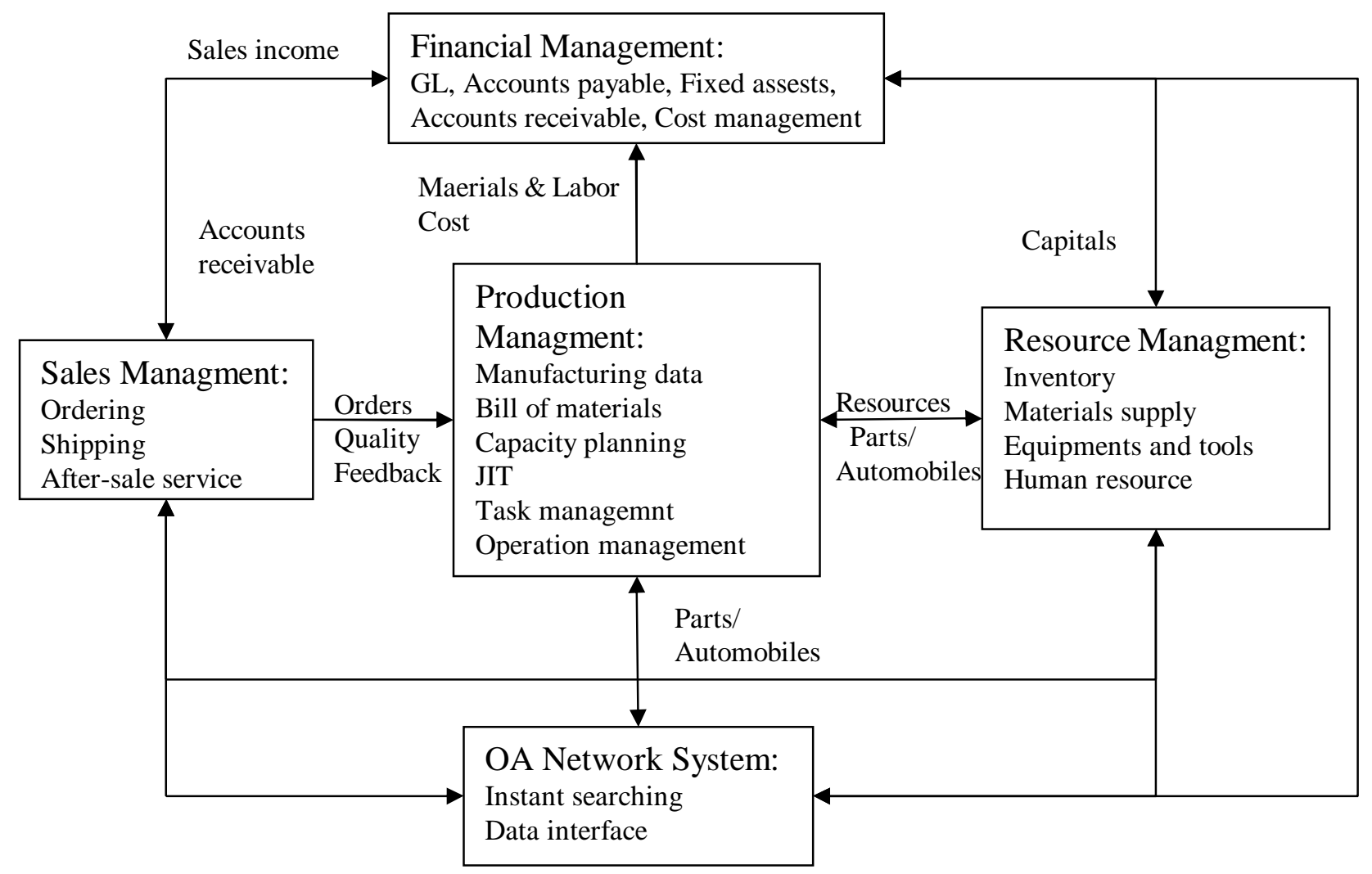

Figure 1. Main modules and data flow of ERP in Chinese automobile manufacturing industry 


\section{Research methodology}

Hypotheses development. ERP projects can be considered as an organization's investment upon information technology. Therefore, its impact on the business performance is of great concern. According to the surveys from APCIS, the implementations of ERP play an important role in inventory reduction and improvements in resource management and manufacturing efficiency. Besides, it contributes to delivering better services to customers. Considering that successful implementations of ERP would improve the capital managing performance and operational efficiency, the hypotheses of this study are stated as follows:

H1: After implementing ERP, there is a significant improvement on capital management.

H2: After implementing ERP, the number of employees has less influence on unit sales.

H3: After implementing ERP, there is a significant improvement on profitability.

Data sample and descriptive statistics. In this study, the listed automobile manufacturers' data from Shanghai Stock Exchange and Shenzhen Stock Exchange between 2000 and 2015 are collected. By the end of 2013, there are 30 automobile manufacturers has implemented or is implementing ERP systems. According to their information reporting and disclosure, 13 listed companies are selected as samples which had successfully implemented ERP system.

Based on the samples, it turned out that the listed automobile manufacturers had implemented ERP system since 1996. In the year of 2002, there was a sharp increase in the number of companies that started ERP projects. It seemed that there was a trend of ERP implementation around that year. Since 2002, the number of companies that implemented ERP system is steadily increasing each year. Up to now, there are few manufactures that have not implement any ERP systems.

Thus, in this study, the automobile manufacturers who had successfully implemented ERP are selected as samples to study the change of business performance.

Research method and design. The research examines several financial and other indicators to monitor the changes of corporations' performance.

First of all, in order to measure the level of capital management, four asset management ratios are selected, namely inventory turnover ratio (IT), accounts receivable turnover ratio (RTR), current assets turnover ratio (CAT) and total assets turnover ratio (TAT). Secondly, the influence of ERP systems on the number of employees and working efficiency is descripted by ES, which is the ratio of number of employees to total sales. Finally, the earning power after implementing ERP is represented by two profitability ratios, namely return of sales (ROS) and return on total assets (ROA). Table 1 listed these measurements and the calculation equations.

Table 1. Performance measurements and calculations

\begin{tabular}{|l|l|l|}
\hline \multicolumn{1}{|c|}{ Measurements } & \multicolumn{1}{|c|}{ Description } & \multicolumn{1}{c|}{ Calculations } \\
\hline $\begin{array}{l}\text { Inventory turnover ratio } \\
\text { (IT) }\end{array}$ & $\begin{array}{l}\text { Measures ERP's function on } \\
\text { inventory reduction }\end{array}$ & $\begin{array}{l}\text { Principle business cost / } \\
\text { average inventory cost }\end{array}$ \\
\hline $\begin{array}{l}\text { Accounts receivable turnover ratio } \\
\text { (RTR) }\end{array}$ & $\begin{array}{l}\text { Measures ERP's function on } \\
\text { capital management }\end{array}$ & $\begin{array}{l}\text { Principle business income / } \\
\text { accounts receivables }\end{array}$ \\
\hline $\begin{array}{l}\text { Current assets turnover ratio } \\
\text { (CAT) }\end{array}$ & $\begin{array}{l}\text { Measures ERP's function on } \\
\text { operational efficiency of current } \\
\text { assets }\end{array}$ & $\begin{array}{l}\text { Sales / average current } \\
\text { assets }\end{array}$ \\
\hline $\begin{array}{l}\text { Total assets turnover ratio } \\
\text { (TAT) }\end{array}$ & $\begin{array}{l}\text { Measures ERP's function on } \\
\text { assets management }\end{array}$ & Sales / average total assets \\
\hline $\begin{array}{l}\text { Number of employees needed for } \\
\text { unit sales (ES) }\end{array}$ & $\begin{array}{l}\text { Measures ERP's function on } \\
\text { working efficiency }\end{array}$ & Number of employees / sales \\
\hline $\begin{array}{l}\text { Return of sales } \\
\text { (ROS) }\end{array}$ & $\begin{array}{l}\text { Measures ERP's function on } \\
\text { profitability }\end{array}$ & Net profit / Sales \\
\hline $\begin{array}{l}\text { Return on total assets } \\
\text { (ROA) }\end{array}$ & $\begin{array}{l}\text { Measures ERP's function on } \\
\text { profitability }\end{array}$ & $\begin{array}{l}\text { Net income / average total } \\
\text { assets }\end{array}$ \\
\hline
\end{tabular}


In this research, the automobile manufacturers that had successfully implemented ERP projects from 2000 to 2015 are selected. Considering the time-delay issues that mentioned in Literature review part of the paper, this research is conducted in the following procedures. Initially, it is concentrated on the year that the samples had finished ERP projects. Assuming that the finishing year of ERP projects is marked by $T$ (year), then the research periods are $T-1$ year, which is the year before implementing ERP, $T+1$ (year) and $T+2$, which is one year or two years after implementing ERP. Therefore, 13 listed companies are selected as samples which had successfully implemented ERP system by the end of 2013. Finally, a paired-T test is conducted in order to make a comparison between before-ERP measurements and after-ERP measurements.

\section{Research results}

The research results are listed in Table 2. These figures were calculated by SPSS using Paired-sample $\mathrm{T}$ test method. Basically, there two comparison groups. One is the comparison of chosen indicators between one-year before ERP implementation and one-year after ERP implementation, i.e. T-1 vs. $\mathrm{T}+1$. The other is the comparison of chosen indicators between one-year before ERP implementation and two-year after ERP implementation, i.e. T-1 vs. T+2.

Table 2. Research results: paired-sample T test

\begin{tabular}{l|c|c|c|c|c|c|c|c}
\hline \multicolumn{2}{c}{ measurements } & \multicolumn{5}{c|}{ Capital Management } & \multicolumn{2}{c}{ Profitability } \\
\cline { 3 - 9 } \multicolumn{2}{l}{ paired-sample } & IT & RTR & CAT & TAT & ES & ROS & ROA \\
\hline \multirow{2}{*}{ T-1 vs. T+1 } & t & -1.193 & 0.734 & 0.330 & -2.129 & 0.649 & -0.304 & -0.231 \\
\cline { 2 - 9 } & p & 0.256 & 0.477 & 0.747 & $0.055^{*}$ & 0.528 & 0.767 & 0.821 \\
\hline \multirow{2}{*}{ T-1 vs. T+2 } & t & -1.894 & -1.602 & -0.984 & -3.684 & 1.989 & -0.349 & 0.937 \\
\cline { 2 - 9 } & p & $0.083 *$ & $0.098^{*}$ & 0.345 & $0.003 * *$ & $0.07 *$ & 0.733 & 0.367 \\
\hline
\end{tabular}

Note: $*$ and $* *$ denote that the observations are significantly different at the 0.10 and 0.01 levels.

\section{Research findings}

Based on the comparison figures in Table 2, the findings are as follows.

H1. When testing "H1: After implementing ERP, there is a significant improvement on capital management", it is found that it can be accepted. For T-1 vs. T+1 paired test, there is no significant observations on inventory turnover rate, receivable turnover rate and current assets turnover rate. However, considering the $\mathrm{T}-1$ vs. $\mathrm{T}+2$ paired test, which is the comparison between one-year before implementing ERP and two-year after implementing ERP, the t-test results are significant for inventory turnover rate and receivable return rate at 0.10 level, as well as total assets turnover rate at 0.01 level. Although the comparisons of current assets turnover rate is not significant, it can reach the conclusion that after implementing ERP systems, there is a significant improvement on capital management performance.

H2. When testing "H2: After implementing ERP, the number of employees has less influences on unit sales", it is found that it can be accepted. For T-1 vs. T+2 paired test, the t-statistics of ES, which is the number of employees needed for unit sales, is significant at 0.1 level. Therefore, it can be concluded that after implementing ERP, the influence of number of employees on sales has declined.

H3. During the test of "H3: After implementing ERP, there is a significant improvement on profitability", there is no significant observations to support this hypothesis. Therefore, H3 cannot be accepted.

Generally, there are significant observations on the paired-sample tests of inventory turnover rate, receivable turnover rate, total assets turnover rate, and ES measurement. Thus, based on this empirical 
research, implementing ERP systems would improve automobile manufacturers' capital management and operational efficiency. The improvement on the profitability performance was not observed. Further analysis and discussions are presented in next section.

\section{Discussions}

The results indicate that ERP system would significantly improve the automobile manufacturers' capital managing performance and operational efficiency. Although the improvement on profitability was not accepted in this study, it cannot conclude that ERP implementation and profitability is not related. ERP system as an efficient tool plays an essential part in business management. It brings a lot of benefits to organizations, including reducing cycle time and information integration. However, the profitability of an organization depends on various factors, such as the quality of service and product, the capabilities of $R \& D$, marketing and financial management, etc. Besides, the investment on information technology is still a large portion of expenditure for manufacturers each year. The internal and external business environments are also changing rapidly. Therefore, ERP systems could update the manufacturers managing philosophy and improve their management capabilities and operational efficiency. The manufacturers must build their own competitive advantage in order to gain earning power.

\section{Limitations and future work}

There are a few limitations and future working directions of this paper that need to be addressed before conclusion. Firstly, this research is primarily based on paired-sample $\mathrm{T}$ test. Other statistic models and methods can also deployed for comparison. Secondly, there are only seven measurements in this study. More indicators can be included for further testing. Thirdly, the research is concentrated on the automobile industry in China. The number of samples is relatively small. Data from other manufacturers, apart from vehicles, can be collected as well. Therefore, these perspectives are considered to be research directions for future work.

\section{Conclusions}

ERP system can be considered as an effective information technology for planning and controlling of all the resources in an organization. In order to gain competitive advantage, more and more corporations choose to implement ERP projects and deploy information systems to manage their business information. This research is an investigation on the relationship between ERP system and corporations' performance, based on the empirical study of 13 automobile manufacturers who had implemented ERP projects successfully from 2000 to 2015 in mainland China. The results show that the application of ERP systems can improve the manufacturers' capital management and their operational efficiency.

\section{Acknowledgements}

This work was financially supported by School of Accounting, Nanjing University of Finance and Economics, the Profession Brand Building Program of Jiangsu Universities, Jiangsu Provincial Education Department (PPZY2015A074).

\section{References}

[1] Saide, and E.R. Mahendrawathi. Knowledge Management Support for Enterprise Resource Planning Implementation. Procedia Computer Science vol.72 (2015), p. 613-621.

[2] C. Holland, B. Light: A Critical Success Factor Model for ERP Implementation. IEEE Software Vol. 9 (1999), p. 30-36. 
[3] N. Welti: Successful SAP R/3 Implementation: Practical Management of ERP Project, Addison Wesley Longman. (1999)

[4] A. Mcafee: The Impact of Enterprise Information Technology Adoption on Operational Performance: An Empirical Investigation. Production \& Operations Management vol. 11(2002), p. 33-53.

[5] Gartner Group: A Vision of Next Generation MRP II (1990).

[6] APICS Dictionary, the fourteenth edition (2013).

[7] D.E. O’Leary, Enterprise Resource Planning Systems: Systems, Life Cycle, Electronic Commerce, and Risk (2000).

[8] P.A. Strassmann: The Business Value of Computers: An Executive's Guide, New Canaan: Information Economics Press. (1990)

[9] R.A. Mcewen, J.E. Hunton and B. Wier: Analysts' Reactions to ERP Announcements. Journal of Information Systems vol.16 (2002), p.31-40.

[10] V.A. Mabert, A.K. Soni and M.A. Venkataramanan: Enterprise resource planning survey of U.S. manufacturing firms. Production \& Inventory management Journal vol. 41 (2000), p. 52-58.

[11] L.N.K. Leonard and T.P. Cronan: A Study of the Value and Impact of Electronic Commerce: Electronic Versus Traditional Replenishment in Supply Chains. Journal of Organizational Computing \& Electronic Commerce vol. 12 (2002), p. 307-327.

[12] I. Madanhire and C. Mbohwa: Enterprise Resource Planning (ERP) in Improving Operational Efficiency: Case Study. Procedia CIRP vol. 40 (2016), p. 225-229.

[13] M. Sumner: Risk factors in Enterprise-wide/ERP projects. Journal of Information Technology vol.15 (2000), p. 317-327. 